\title{
The perceptions of gender roles in parenting: An in-depth interview study
}

- Le Phuoc Thuc Nhi

University of Florida, USA

\section{ABSTRACT:}

This ethnographic research paper addresses gender roles changes in parenting as perceived by a diverse population at a U.S. university. Gender roles in parenting may seem simple at first glance with the traditional stereotype of mothers being the caregivers and the fathers breadwinners. However, this line between the genders and the roles they ought to play in parenting is gradually being blurred as society progresses. For a deeper insight into this movement, in-depth interview was used to understand perceptions of people from different age groups, genders, backgrounds, and nationalities from a U.S. university in a more holistic manner. Data were collected from interviews with 16 participants of American, Italian, Honduran, Croatian, Finnish, Indian, German-Nepali, Bosnian, Danish and Thai nationalities. The findings show that the perceptions of people towards parental gender roles have become more "equal" over the course of time and that there are various causes related to these changes including education, living environment, biological make-up and historical factors.

Keywords: perception, gender roles, parenting, in-depth interview

\section{Gender Roles in Parenting}

Traditionally, parental gender roles involve mothers being nurturers, looking after the family, doing household chores, and being responsible for children's social and emotional development. The father, on the other hand, is the breadwinner, and tends to place more emphasis on the children's intellectual learning (Coleman, Ganong, Clark, and Madsen, 1989: 329). However, gender ideologies have become more equal in society nowadays. Besides mothers joining the workforce to create a dual-earning for the family, the fathers also tend to share more child-rearing responsibilities with the mother, though she still takes the primary caretaking role (Wille 1995: 805). Also mentioned was the case of stay-at-home fathers; they take on chores that are traditionally considered "feminine" and have "similar levels of traditional feminine and masculine characteristics but less traditional gender role attitudes" (Fischer \& Anderson, 2012: 16). The popular culture of the U.S., as revealed from an online magazine, Parents.com, (September 2008 and September 2014), shows a great deviation in parenting in comparison to the "traditional" gender norms. Even though the websites mentioned the significant changes in parenting and how the roles are becoming more equal, they still indicate the necessity of traditional ones for such reasons as each gender are better at certain aspects of parenting. This ethnographic research was used to understand the perceptions of people from different age groups, genders, backgrounds, and nationalities towards parenting roles and examine how the perceptions have been changed.

\section{Trang 104}




\section{Related Studies}

In 1995, a study conducted by Wille investigated the different societal and cultural factors that influence gender roles in parenting. The study, which involved 70 European American families with 6-month-old infants, revealed the tendency of mothers being more involved with the infants while the fathers worked outside the home more hours per week compared to the mothers. Additionally, fathers and mothers among the participants agreed upon the fact that mothers were better caretakers for the infants. Besides, parental reports and observations revealed that mothers were more involved with the infants and fathers were employed outside the home more hours per week than mothers. Both parents rated the mother as a better caretaker of the infant than the father. The mother rated the father's caretaking abilities higher than he rated himself. Paternal concerns about separations related to employment were also influenced by maternal employment factors.

Clearly, it is often claimed that gender ideologies influence the domestic division of labor. The study by Bulanda (2004) through the National Survey of Families and Households $(\mathrm{N}=1,088)$ assessed the effect of both mother's and father's gender ideology on two measures of paternal involvement. Whereas egalitarian fathers demonstrate greater involvement than traditional fathers, mother's gender ideology failed to predict paternal involvement. Egalitarian mothers do not appear to negotiate greater father involvement successfully.

Zuo and Tang (2000) conducted research that attempted to look at possible reasons behind ideological shifts towards egalitarianism. The findings suggested this to be egalitarianism to be because men benefited materially from their wives' financial contributions to the family. More specifically, the study found that men of lower breadwinner status and women of higher status are less likely to hold conventional gender ideologies.
The decline in men's breadwinner status tends to promote egalitarian ideology among men. Generally, the findings show that there was an ideological shift of men toward egalitarianism because men benefit materially from their wives' financial contributions to the family. The empirical results suggest that both genders are moving in the direction of egalitarianism. Men of lower breadwinner status and women of higher status are less likely to hold conventional gender ideologies. The decline in men's breadwinner status tends to promote egalitarian ideology among men.

Another study by Hill and Sprague (1999) looked at the influence of race and gender roles in parenting of black and white families. From the surveys collected from a non-random sample of parents in 202 African American and 204 European American families in two large metropolitan school districts, they found that race and social class interact to shape the intergenerational construction of gender in families. The authors use data from surveys completed by a nonrandom sample of parents in 202 African American and 204 white families in two large metropolitan school districts to examine the impact of gender, race, and class on parents' self-reports of their immediate priorities and longterm goals for their children, their view of the parenting role, and their discipline strategies. The findings are consistent with multicultural feminist theory: Race and social class interact to shape the intergenerational construction of gender in families.

In general, the studies reviewed above demonstrate that the changes in gender roles occurred because of such factors as men's perceptions of gender ideologies, economical factors involving jobs. Besides, the quantitative method generates a broad picture of the perceptions of gender roles and factors affecting these pictures. None of the studies reviewed used interview to further dwell into individual 
experiences towards the concepts of gender roles and parenting and how people actually experienced these changes. Thus, this study was set out to explore these aspects.

\section{Methods}

Sampling

Sixteen participants were invited to participate in the research using a purposive sampling method based on criteria of sex/gender balance (an equal number of males and females), age range, nationality ( 8 Americans and 8 international participants) and backgrounds (see Appendix A). People in the sample received a request to take part in the interviews by either email or Facebook messaging. However, out of the 16 invited participants, 4 did not respond so the snowball sampling approach was used after the purposive sampling to invite 4 other participants to take part in the study. This was accomplished by asking those who had already been interviewed to introduce more people. Finally, consent from 16 people to participate in interviews for the ethnographic research was received.

\section{In-depth interview}

In-depth interviewing was chosen for the current study. It is "a qualitative research technique that involves conducting intensive individual interviews with a small number of respondents to explore their perspectives on a particular idea, program, or situation" (Boyce \& Neale, 2006. p.3). The size of the sample was considered following the suggestion by Baker, Edwards \& Doidge (2012, p. 10) for a shoot for a sample of at least 12 respondents. As mentioned in the section on sampling, the current study actually was carried out with the participation of 16 respondents. The interview for each individual lasted for approximately 10 minutes. Clearly, the length for an interview varies in different studies but it usually ranges from between 10 and 30 minutes and up to an hour (http://marketstreetresearch.com/research- methods/in-depth-interviews/). In this study, the length of 10 minutes deems to be sufficient to serve the purpose of the study to explore the participants' perceptions of gender roles in parenting and how they realized the changes in gender roles over the time.

Before the interview, a briefing of the topic in research, the aim, and basic information about the interview (length, number of questions, etc.) was given to the interviewees. The interviewees were also assured of their right to withdraw anytime they felt uncomfortable. All participants were clearly informed that they would be audio recorded and that their answers were being noted. The questions for the interview were easy to understand and as open-ended as possible to facilitate further discussions. The three questions that were posed during the interview were:

- What are your perceptions of gender roles in parenting?

- What do you think are the factors/what aspects of your background do you think have caused you to have such opinions?

- Do you think gender roles in parenting have changed over time? If yes, how have they changed? What do you think are the factors that have led to those changes? If no, why not?

During the interviews, occasional commenting was done to show sympathy whenever the interviewer felt it was right to do so in order to build rapport. When the interview was over, the interviewer debriefed and told the interviewees that all their information and identity would be kept confidential and that they could ask for more information regarding the findings of the research after the study has been carried out.

\section{Data analysis}

An inductive content analysis process was adopted to examine the interview notes. The notes were grouped into themes that answered the research questions as mentioned above (see

\section{Trang 106}


Appendix B). Reflections on the findings from the interviews are presented in the following section.

\section{Findings and Discussion}

\section{The perceptions of gender roles in parenting}

The use of inductive content analysis shows that the participants were aware of the "traditional" gender roles in parenting. They all stated, in one way or another, that the mother is traditionally considered the nurturer, caregiver, and is associated with household chores, while the father is the leader and breadwinner of the family, and goes to work. Additionally, 19 year-old male participants from Croatia, India, Honduras, and one 54 year-old American father reflect on how the image of the father is associated with strictness, discipline, and a "tougher teaching style" in their cultures. For example, the mother is often more tender, loving, and is someone that "you went to when you didn't like the discipline that you were getting from the father", said the 54 years old American male. The 19-year-old interviewee, M., from Honduras also talked about his culture where "the mom has to be emotionally attached to the kid. I think that is what is expected of them." Meanwhile, in the Croatian culture, a 19 year-old male stated that through observing children interact with their mothers and fathers, it can be seen that with their fathers, "there's a clear essence of respect, but not respect, let's say fearful respect, the one that religious people claim they have for god". He also said that children tended to be more relaxed around mothers and more willing to voice their thoughts.

Another theme that came up in the interview was decision-making among parents, which was pointed out by two research participants. A 54year-old male recalled that his father made almost all of the decisions. And A., an 18 years old Nepali-German who took a Family and Marriage course in a U.S. university said that her mother and father have equal say in her family and that decisions are made together.
The participants also talked about the topics or activities that they often discussed, found easier talking to, or did with their mothers versus those with their fathers (reported by 5 members). For instance, a 32 year-old American female, who is also an anthropology major graduate student, talked about clothes shopping with her mother, something that she does not do with her father. Or K., a 19-year-old male from Finland mentioned talking to his father about politics and sports and education to his mother. The whole discussion with participants about their perceptions on gender roles in parenting reflects that their notions tend to be more equal and modern. However, there are certain interests of each gender (such as the topics discussed with each parent) that is maintained, as pointed out by Nick Shell in his article on Parents.com, "The Cross Gendered Roles of Modern Parents", and by Fischer and Anderson in "Gender role attitudes and characteristics of stayat-home and employed fathers." The topics generally discussed with mothers are related to shopping and clothes and those discussed with fathers involve sports and politics, as reported by the participants.

\section{Causes for those perceptions}

The interviews show that education plays a great role in shaping people's perception of gender roles in parenting. Two participants talked about their United World College (UWC) education, which focused on the international, global aspect of learning. They claimed that having been a UWC student, they have a more egalitarian view towards gender roles in parenting. A 32 year-old American female said that studying Anthropology, and Women's Rights in college has given her "critical lens and look at things that are considered normal in society", and question "why are they normal? And is it actually right?" Additionally, culture is a major influence to 9 participants' (mostly international participants) perceptions. For example, in the Nordic culture, parenting tends to 
be more liberal, people are more open-minded and there is more emphasis on women's rights (mentioned by 2 people). While in the Indian culture, the patriarchal society makes the father the head of the family. It is possible that there is little mentioning of culture among American participants because the American culture is a melting pot of various cultures. The American interviewees mentioning culture, however, in that they had family backgrounds from other cultures such as Italy, Cuba, etc.

Some participants talked about the effect of the environment they were brought up in, such as the way they were raised, their interaction with parents and experience in an international environment. An instance is a 19 year-old Bosnian female who felt equality among her parent's roles as she "considered them friends." Three people mentioned the influence of their exposure to "women's rights", and modern movements. For a 19 year-old Finnish male, being the son of a feminist mother has greatly shaped his perceptions on gender roles in parenting. The factors of upbringing environment and interaction with parents could not be found in literature by Cotter, Hermsen and Vanneman (2011) or Fischer, Jessica, and Anderson (2012). It is possibly because their participants of study were mostly older adults or people who were parents or were expecting while in this study, there is a wide range of age groups, gender, nationalities and backgrounds, diversifying the participants group.

In the interviews, three participants talked about the biological make up of parents leading to the different perceptions of parenting roles. For examples, they mentioned that the mother gives birth to children and nurses them; hence, the father has to go to work to assist in providing for the family, during the phase of the child's infancy. This perception supports Fischer and Anderson's study in 2012 which focused on biological factors and children raising.

\section{Gender roles in parenting have changed}

It was apparent from online parenting sites that nowadays there are more modern and egalitarian views about gender roles in parenting. This hints the changes that are occurring day by day in families and society. Responses from the interviewees in the current study also reported the changes that they perceive in their communities and in the society today. However, there are slight variations in the extent to which they think the parental gender roles have changed. For example, 2 people, both 19 years of age, thought the changes are not very significant, one (72 years old, American male) said the changes are very significant, while the others said there have been changes but did not mention the level of change. The difference among the perceived extent of change may be due to the fact that the older the participants are, the more changes they have seen and experienced throughout their lifetimes. The perceived changes include a more egalitarian view of the gender roles in parenting and more open communication between the parents. This data supports Katz-Wise, Priess, and Hyde (2010: 19), who documented a more equal parenthood and claimed that "egalitarian" allows both partners to contribute to family life.

As for responsibility sharing, all the participants mentioned female parents joining the workforce, and gaining earnings for the family. In other circumstances, the fathers might become stay-at-home fathers. This is when the fathers do not go to work and, instead, take the primary responsibility in caring for the child, just as Fischer and Anderson said in their article, stay-at-homefathers have "similar levels of traditional feminine and masculine characteristics, but less traditional gender role attitudes" (Fischer \& Anderson 2012: 16). B, a 72 year-old American talked about three generations of his family. In his parent's generation, his mother raised the children while his father worked. In his own generation, he co-

\section{Trang 108}


parented with his wife. His son, however, is a stayat-home-father. This finding is parallel with the findings in the studies of Zuo and Tang (2000) that when the fathers' breadwinner status is lower, they tend to have a less conventional view of parental roles.

In addition, five people talked about historical impacts on this issue, taking World War II, the Great Depression, and the Industrial revolution as causes. These are times when women had to enter the work force because there was a lack of labor. In addition, globalization must have had a noticeable influence on the gender roles in parenting. More specifically, the media, social media, and the Internet have spread messages about parenting or promoting equality among the genders in families from one country to another. Modernization, especially the development of appliances is also a cause for the change, as mentioned by the participants, as they allow family members to have time for other jobs such as working and earning. Advertisements also influence the human subconsciousness, and women go out to work due to the availability of a variety of job choices. This cause of gender roles was not mentioned in the scholarly articles reviewed in this research; yet, it makes great sense in the way it has shaped society. The last reason for the changes in gender roles in parenting was claimed to originate from the feminist movement and egalitarianism.

\section{Conclusion}

Despite the fact that "traditional" stereotypes of fathers and mothers are deeply rooted in our subconsciousness, the perceptions of gender roles in parenting have changed over time. This ethnographic study has clearly shown the great impact that history, modernization and movement of the U.S. society has on the breaking of these stereotypes, forming new trends in parental roles. The new trends found in this study indicate that parents, as well as many people of the younger generations, adopt a more equal view of gender roles in parenting. The findings of the current study have pointed out some causes for current perceptions on gender roles, which were not covered in the references used in this study. These causes include the impact of World War II, the Great Depression, the Industrial revolution; modernization and globalization which have led to changes in civil rights and women's movements and women's status with higher level degrees or jobs. With the participation of 16 participants from diverse places, the findings of the study indicate that these participants' backgrounds have had the most dominant influence in their view of gender roles in parenting. Other factors are associated with age groups and genders. Older participants tended to see more changes in generations of parents, and women joining the work force - putting their husbands in the position to help their wives with the housework.

However, these findings of the current study again asserts that the traditional roles of mothers as care givers and house wives still exist (Wille, 1995) despite the fact that egalitarian ideology of fathers leading to more involvement with work for men (Bulanda, 2004). Besides, the breadwinner status of fathers is challenged when both parents both accept a more egalitarian ideology (Zuo and Tang, 2000). Finally, race and social class interaction also affect gender role.

As there are only 16 participants in this study, it is hard to generalize its findings. To overcome this drawback, future research could be conducted on a wider and possibly even more diverse population. Furthermore, more background research should be done for more varied perspectives from former studies. The current study did not identify careers and socio-economical conditions in relation to the perceptions of gender roles of the in-depth interview sample. It would give more insights if these factors had been explored. Future research would gain even deeper insight if cases of gender roles in same-sex marriages, in single parenting 
circumstances, or in extended families, etc., could be studied. Further research on families who are deviant-from-the-norm (either not including both male and female parents, or including more family members living together who may also play crucial roles in the family) will help researchers see how the roles are distributed compared to the basic family structure of a mother, a father, and children. Besides, a study to compare gender roles of parenting in nuclear families with other kinds of family would shed more light on the topic.

\section{Nhận thức về vai trò giới trong việc làm cha mẹ: một nghiên cứu phỏng vấn sâu}

- Lê Phước Thục Nhi

Đại Học Florida, Hoa Kỳ

\section{TÓM TÁT:}

Nghiên cứu này tìm hiểu nhận thức về sự thay đổi của vai trò giới trong việc làm cha mẹ của một nhóm khách thể gồm nhiều sắc tộc khác nhau tại một trường đại học ở Hoa Kỳ. Vai trò giới trong việc làm cha mẹ thoạt nhìn dường nhu đơn giản với hình ảnh đặc trưng: mẹ là người chăm sóc và cha là người trụ cột gia đình. Tuy vậy, ranh giới giữa các giới và vai trò mà các giới phải thực hiện trong việc làm cha mẹ dần dần có sự đổi thay do xã hội ngày càng tiến hóa. Để hiểu thêm về sự thay đổi này, nghiên cứu này đã sử dụng kỹ thuật phỏng vấn sâu để tìm hiểu tổng thể về nhận thức của các khách thể khác nhau về độ tuổi, giới tính, nền tảng gia đình và quốc tịch tại một trường đại học ở Hoa Kỳ. Cúr liệu được thu thập từ phỏng vấn với 16 khách thể có các quốc tịch như Hoa Kỳ, $\dot{Y}$, Hông-duy-ra, Croatia, Phần Lan, Ân Độ, Đức-Nê-pan, Bosnia, Đan Mạch, và Thái Lan. Kết quả cho thấy rằng nhận thức của các khách thể về vai trò giới trong việc làm cha mẹ đã trở nên "bình đẳng" hơn theo thời gian và có nhiều nguyên nhân dẫn đến sự thay đổi này bao gồm giáo dục, môi trường sống, yếu tố sinh học và lịch sư.

Từ khóa: nhận thức, vai trò giới, làm cha mẹ, phỏng vấn sâu 


\section{REFERENCES}

[1]. Baker, S. E., Edwards, R., \& Doidge, M. (2012). How many qualitative interviews is enough? Expert voices and early career reflections on sampling and cases in qualitative research.

[2]. Boyce, C., \& Neale, P. (2006). Conducting in-depth interviews: A guide for designing and conducting in-depth interviews for evaluation input (pp. 3-7). Watertown, MA: Pathfinder International.

[3]. Bulanda, R. E. (2004). Paternal involvement with children: The influence of gender ideologies. Journal of Marriage and Family, 66(1), 40-45.

[4]. Coleman, M., et al. (1989). Parenting perceptions in rural and urban families: Is there a difference? Journal of Marriage and the Family, 329-335.

[5]. Conroy, F. (2014). The Good Father. Parenting.com. Meredith Corporation, Web. 16 September 2014.

[6]. Cotter, D., Joan M. H, and Reeve, V. (2011). The End of the Gender Revolution? Gender Role Attitudes from 1977 to 20081. American Journal of Sociology, 117(1), 259-289.

[7]. Dufur, M. J., et al. (2010). Sex Differences in Parenting Behaviors in Single-Mother and Single-Father Households. Journal of Marriage and Family, 72 (5), 1092-1106.
[8]. Fischer, J., and Veanne, N. A. (2012). Gender role attitudes and characteristics of stay-athome and employed fathers. Psychology of Men \& Masculinity, 13 (1), 16.

[9]. Hill, S. A., \& Sprague, J. (1999). Parenting in black and white families: The Interaction of Gender with Race and Class. Gender \& Society, 13(4), 480-502.

[10]. Katz-Wise, S. L., Heather A. P., and Janet S. H. (2010). Gender-role attitudes and behavior across the transition to parenthood. Developmental psychology, 46(1), 18.

[11]. Shell, N. (10 October 2011). The Cross Gendered Roles of Modern Parents. Parents.com. Meredith Corporation, Web. 16 September 2014.

[12]. Sterk, C. E. (2000). Tricking and tripping: Fieldwork on prostitution in the era of AIDS.

[13]. Wille, D. E. (1995). The 1990s: Gender differences in parenting roles. Sex Roles, 33(11-12), 803-817.

[14]. The Demands of Motherhood. Parents.com. Meredith Corporation, 2 September 2008, Web. 16 September 2014.

[15].Zuo, J., \& Tang, S. (2000). Breadwinner status and gender ideologies of men and women regarding family roles. Sociological Perspectives, 43(1), 29-43. 
Appendix A: BACKGROUNDS OF VOLUNTEER PARTICIPANTS

\begin{tabular}{|c|l|l|l|}
\hline Participant & Age range & Gender & Nationality \\
\hline 1 & Over $70(\mathrm{~B})$ & Male & American \\
\hline 2 & Over 50 $(\mathrm{R})$ & Male & American \\
\hline 3 & $18-20(\mathrm{M})$ & Male & Vietnamese American \\
\hline 4 & $18-20(\mathrm{~A})$ & Male & American \\
\hline 5 & $18-20(\mathrm{~K})$ & Female & American \\
\hline 6 & $18-20(\mathrm{~S})$ & Female & American \\
\hline 7 & Over $30(\mathrm{~K})$ & Female & American \\
\hline 8 & $18-20(\mathrm{~V})$ & Female & American - Italian \\
\hline 9 & $18-20(\mathrm{M})$ & Male & Honduran \\
\hline 10 & $18-20(\mathrm{~A})$ & Male & Croatian \\
\hline 11 & $18-20(\mathrm{~K})$ & Male & Finnish \\
\hline 12 & Over $20(\mathrm{~S})$ & Male & Indian \\
\hline 13 & $18-20(\mathrm{~A})$ & Female & German-Nepali \\
\hline 14 & $18-20(\mathrm{~A})$ & Female & Bosnian \\
\hline 15 & $18-20(\mathrm{H})$ & Female & Danish \\
\hline 16 & $18-20(\mathrm{~N})$ & Female & Thai $($ Chinese origin $)$ \\
\hline
\end{tabular}




\section{Appendix B: INTERVIEW RESPONSES}

\begin{tabular}{|c|c|c|}
\hline Research question & $\begin{array}{l}\text { Main themes and numbers of } \\
\text { participants }\end{array}$ & Notes \\
\hline \multirow[t]{3}{*}{$\begin{array}{l}\text { What are your } \\
\text { perceptions of gender } \\
\text { roles in parenting? }\end{array}$} & $\begin{array}{l}\text { Awareness of "traditional" gender } \\
\text { roles in parenting: the mother is the } \\
\text { nurturer, caregiver, is associated with } \\
\text { household chores. The father is the } \\
\text { leader of the household, breadwinner, } \\
\text { goes to work (All } 16 \text { people) }\end{array}$ & $\begin{array}{l}\text {-B, American, } 72 \text {, said that } \\
\text { before world war II, women } \\
\text { took full responsibility in } \\
\text { child-rearing in America } \\
\text { and it was not until WWII } \\
\text { that women began joining } \\
\text { the workforces }\end{array}$ \\
\hline & $\begin{array}{l}\text { Participants from Croatia, India, } \\
\text { Honduras, and one American who is a } \\
\text { father reflects on how the image of the } \\
\text { father is also associated with } \\
\text { strictness, discipline, and a "tougher } \\
\text { teaching style" in their cultures. } \\
\text { Whilst, the mother is often more } \\
\text { tender, loving and is someone that } \\
\text { "you went to when you didn't like the } \\
\text { discipline that you were getting from } \\
\text { the father" (R, American, 54). }\end{array}$ & $\begin{array}{l}\text { "The mom has to be } \\
\text { emotionally attached to the } \\
\text { kid, I think that is what is } \\
\text { expected of them" (M, } \\
\text { Honduras, 19) } \\
\text { "Through observation in } \\
\text { the way children interact } \\
\text { with their mothers and } \\
\text { fathers, you can see that } \\
\text { with their fathers, there's a } \\
\text { clear essence of respect, but } \\
\text { not respect, let's say fearful } \\
\text { respect, the one that } \\
\text { religious people would } \\
\text { claim they have for god. } \\
\text { While with the mother, } \\
\text { people seem more relaxed } \\
\text { and willing to speak about } \\
\text { what they're thinking of." } \\
\text { (A, Croatia, 19) }\end{array}$ \\
\hline & $\begin{array}{l}\text { Decision making ( } 2 \text { people mentioned } \\
\text { this) } \\
\text {-R, American, 54: "My father made } \\
\text { almost all the decisions" } \\
\text { - A, Nepali-German, 18: Mother and } \\
\text { father have equal say and decisions } \\
\text { are made together }\end{array}$ & \\
\hline
\end{tabular}




\begin{tabular}{|c|c|c|}
\hline & $\begin{array}{l}\text { Topics discussed with mother and } \\
\text { father }\end{array}$ & \\
\hline \multirow[t]{5}{*}{$\begin{array}{l}\text { Causes for those } \\
\text { perceptions }\end{array}$} & $\begin{array}{l}\text { Education } \\
\text {-Going to college, major }\end{array}$ & $\begin{array}{l}\text {-Going to UWC ( } 2 \text { people) } \\
\text {-K, American, 32: Student } \\
\text { of Anthropology, studied } \\
\text { anthropology, women's } \\
\text { rights in college; this gave } \\
\text { her "critical lens and look } \\
\text { at things that are considered } \\
\text { normal in society" and } \\
\text { question "why are they } \\
\text { normal? And is it actually } \\
\text { right?" }\end{array}$ \\
\hline & $\begin{array}{l}\text { Culture }(9 \text { people, mostly } \\
\text { International participants }) \\
\text {-Nordic culture: liberal, open-minded, } \\
\text { emphasis on women's rights ( } \\
\text { people) } \\
\text { - Indian culture: dad head of the } \\
\text { family }\end{array}$ & $\begin{array}{l}\text { American participants } \\
\text { rarely mentioned culture } \\
\text { because the American } \\
\text { culture is a melting pot of } \\
\text { various cultures. }\end{array}$ \\
\hline & $\begin{array}{l}\text { Environment } \\
\text {-The way one was raised } \\
\text {-Interaction with parents } \\
\text {-International environment }\end{array}$ & $\begin{array}{l}\text { A, } \quad \text { Bosnian, } 19: \\
\text { "considered them friends" }\end{array}$ \\
\hline & $\begin{array}{l}\text { Exposure to "women's rights", } \\
\text { modern movements ( } 3 \text { people) }\end{array}$ & $\begin{array}{l}\mathrm{K} \text {, Finnish, 19: His mother } \\
\text { is a feminist }\end{array}$ \\
\hline & $\begin{array}{l}\text { Biological make up of parents } \\
\text {-Females give birth and nurse children } \\
(3 \text { people) }\end{array}$ & \\
\hline \multirow[t]{2}{*}{$\begin{array}{l}\text { Do you think gender } \\
\text { roles in parenting have } \\
\text { changed over time? } \\
\text { What led to these } \\
\text { changes? }\end{array}$} & $\begin{array}{l}\text {-Not very significant changes }(2 \\
\text { people, both 19) } \\
\text {-Significant changes (1 person, } 72) \\
\text {-Others said there has been a change, } \\
\text { they did not mention the extent. }\end{array}$ & \\
\hline & $\begin{array}{l}\text { More egalitarian between the gender } \\
\text { roles in parenting } \\
\text {-More open communication between } \\
\text { the parents }\end{array}$ & $\begin{array}{l}\text {-Father not necessarily the } \\
\text { leader of the house, both } \\
\text { parents have more equal } \\
\text { say }\end{array}$ \\
\hline
\end{tabular}

Trang 17 


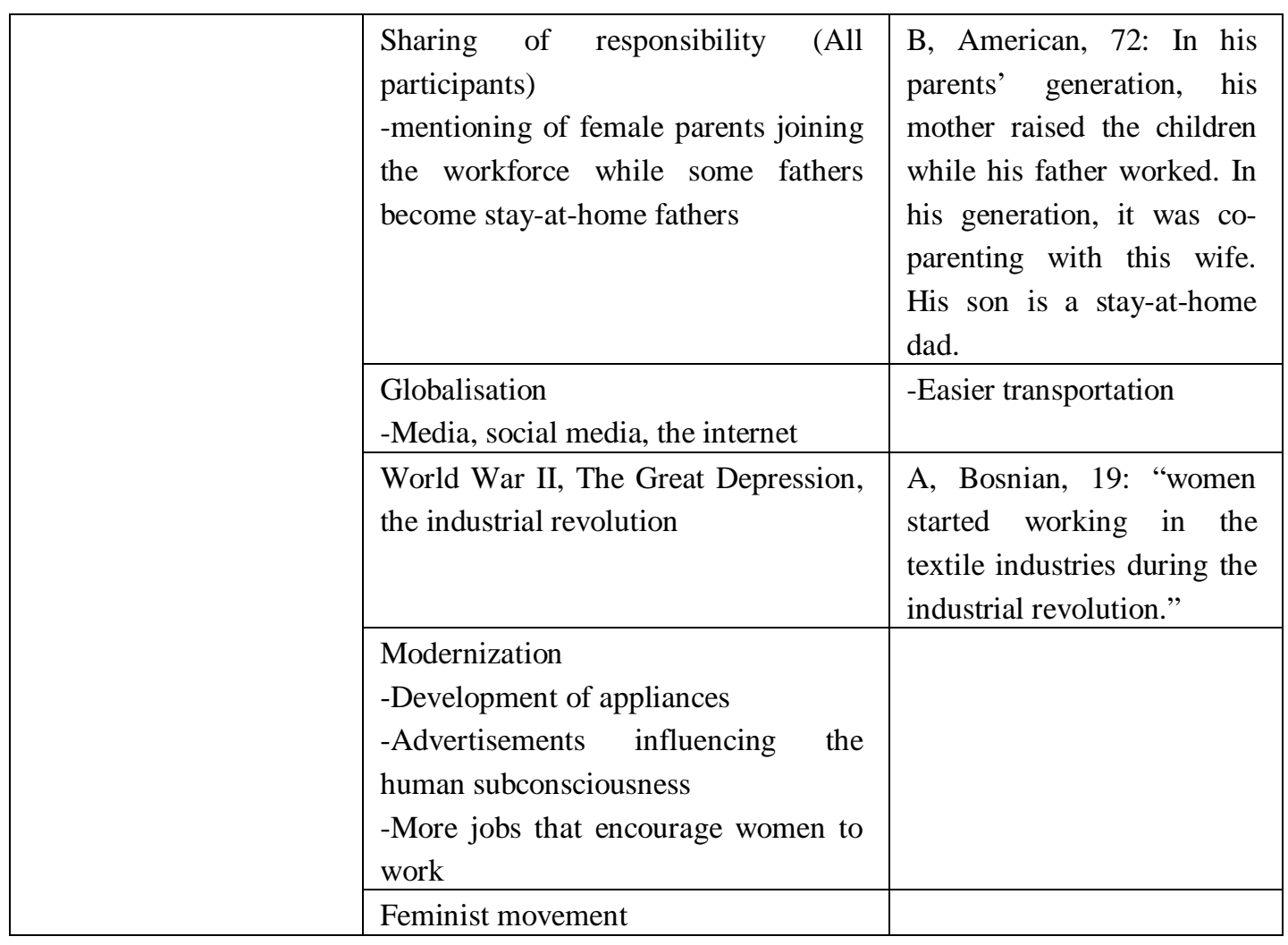

